\title{
The influence of consumer protection on the satisfaction of airline passengers
}

\author{
Nicoleta Andreea NEACȘU \\ Transilvania University of Brașov, Brașov/România \\ andreea.neacsu@unitbv.ro; deea_neacsu@yahoo.com \\ Anca MADAR \\ Transilvania University of Brașov, Brașov/România \\ madaranca@gmail.com; ancamadar@unitbv.ro
}

PICBE | 112

\begin{abstract}
In a society in continuous development, air transport is no longer a luxury, but a means of transportation for everyone. As a result of rising living standards, reducing the cost of air travel compared to other means of transport, more and more people prefer to travel by air even at short distances. The steady increase in popularity and accessibility of air transport has led, in some cases to a decrease in the quality of services provided by air transport companies and in violation of consumer rights. The evolution of consumer protection has influenced positively the quality of air transport services by imposing certain obligations and offering a very high level of security, which increases passenger satisfaction. This article aims to quantify the passanger satisfaction and how the rights and interests of travelers in Romania are protected. In this respect, the authors carried out a quantitative research done among consumers of air transport services. Through a quantitative exploratory empirical research, 110 people were interviewed. The results obtained have made it possible to determine the extent to which the airline they have called upon, succeeds in meeting their expectations and satisfying them, and their rights have been respected. At the same time, passengers' perception of the quality of air services were also quantified. Based on the results, the authors make some recommendations to airline companies' management: to develop effective strategies to protect the rights and interests of travelers, to permanently identify the needs of the actual customers.
\end{abstract}

Keywords: consumer protection, air transport services, air quality, passenger rights, quantitative research.

\section{Introduction}

This paper aims the linking between the permanent growth of the popularity and accessibility of air transport, and the evolution of the quality of the services provided by the air transport service companies. The article will present the role of the National Authority for the Protection of Consumers actions in the field of air transport and their effects on the quality of services.

First, will be defined the theoretical aspects that are related to this subject and which will help to better understand the purpose, ideas and objectives of this work. A summary of the Romanian legislation on consumer protection is presented in order to identify the most frequent violations of consumer rights in this field.

A marketing research based on a survey was conducted to track respondents' opinions and attitudes about the protection of air transport consumers.

The main hypotheses from which this research was undertaken were:

- In the air transport market the quality of services has increased; 
- Most consumers trust the work of the National Consumer Protection Authority on the air transport market;

- The phenomenon of globalization has influenced the observance of the rights of air transport consumers.

The paper ends with conclusions on the link between the phenomenon of globalization, the increasing popularity of air transport and the frequency of respecting consumer rights in this field.

\section{Literature review}

Consumer protection is one of the main coordinates of social policies promoted by the government of any state. At the same time, due to the importance it presents, it must be a stand-alone policy with its own objectives, priorities and instruments. Under the conditions of a real democracy that characterizes a market economy, as is the one specific to countries within the European Union, Consumer Protection appears to be a very important aspect. The general regulation of the quality of products and services, from the perspective of consumer protection, is given in Romania by G.0. No. 21/1992 (http://www.anpc.gov.ro).

The purpose of this normative act is to protect citizens by the state in their capacity as consumers. The main actors of the market economy are economic agents and consumers (Picu, Capota, 2011). The economic agent is the one who aims to carry out his activity by selling goods or services to consumers. It is the consumer who purchases a product or service, so he has more rights and fewer obligations than an economic agent. The consumer plays one of the most important roles in the market mechanism, being the reference for all the actions undertaken by producers, service providers and traders.

In a market economy, competition ensures consumer protection through indirect influence on economic agents. Customers have the choice of where to buy the goods or services from a variety of aspects, such as the quality of products or services, their price, and staff. In order to cope with this competition, economic agents need to consider applying the TQM principles, which "The vast majority of authors agree that is, above all, a new philosophy, a new model of enterprise culture, with the aim to orient towards customers all its activities and processes and optimize them so that they could bring long-term benefits" (Madar, 2015). Viviane Reding, member of the European Parliament, said that "a confident consumer is the best positive news for our single market" (http://www.anpc.gov.ro/galerie). From the perspective of law, quality is defined in Government Ordinance no. 21/1992 as: "the set of properties and characteristics of a product or service that gives it the ability to satisfy the consumer, according to its purpose, the explicit or implicit needs" (Bolos, Leaua, 2002). Despite this, consumers are often confronted with a number of imbalances in market relations that affect them economically, educationally, or health. These are often caused by the fact that the economic agents only aim to increase the profit of the organization, not taking into account, in some cases, even the legislation. In order to ensure the protection of consumer rights, social, governmental and non-governmental interventions were required (www.infocons.ro) and the National Authority for Consumer Protection (NACP) was created.

NACP is the institution that has the competence and the legal right to solve the problems that arise between a consumer and a legal person that has as a business the provision of goods and services to the final consumers (http://www.anpc.gov.ro) and is a specialized body of the central public administration. It has the role of implementing the 
Government's policy and strategy in preventing and combating practices that may harm consumers' lives, health, safety or economic interests" (Neacșu, 2011).

The strategic objective of the institution is to ensure a high level of consumer protection in a fair competitive market that is to its benefit. A particular emphasis on consumer protection is put on ensuring safe products and services. It aims to achieve consumer protection objectives at the level of European directives: lowering the risk of marketing dangerous products on the market, lowering the level of harmful consumer transactions, enabling consumer decision-making through education and training, streamlining the process of claiming rights and recovering damages. The principle that governs the relationship between consumers and economic operators is transparency, based on a correct, complete and accurate communication and information to help the consumer make the right decisions appropriate to his needs. All of these aspects generate confidence in existing products and services on the market.

A remarkable breakthrough is being made on the rights of air passengers. Still, there are many details that can be improved.

The evolution of consumer protection has influenced the quality of air transport services positively by imposing obligations and offering a very high security level, which is considered to be one of the most important aspects in this area. Airline companies in Romania have shown highly qualified staff and a permanent assessment of the planes. Air transport is considered the safest type of transport after accident reports. In addition to the positive influence of consumer protection, there are also parts where there is much work to do. As long as consumer rights continue to be violated, as complaints from airline customers are received, as the airline market evolves, there will always be something to improve in the field of consumer protection. The materialization of the concept of consumer protection by creating an institutional framework at global, European and national level has led to the development of specific legislation regulating consumer protection (Neacșu, 2018).

At present, air travel is a crucial source of global power for a country, as it can influence the global perceptions of the state of origin and, in general, aviation deletes borders, removing distances and connecting people, cultures, companies, innovation and opportunity. Traian Sbora, Gheorghe Tănase and Dumitru Şerban in their book "Economy, Transport Organization and Planning" have defined the concept of airline as a state or private enterprise that owns, hired, loaned or otherwise owned aircraft, with which it carries out an airline charge for a fixed hour or on request (Sbora et al., 1979). The main features that position air transport as a prime transport are: speed, efficiency, accessibility, comfort, safety (Cristea et al., 1980, pp 125-170). Air travel in comparison with other means of transport is possible in a very short time. In the world of globalization in the 21 st century, time is an important factor in space. It has the power to change spatial patterns. The shortest flight data analysis (time gap) also showed that shorter travel times and lower travel considerably increase travel costs (Dudás, Boros \& Vida, 2017).).

The efficiency of air transport is the ability to carry out under constant conditions of regularity and frequency, air racing. Regularity refers to the ratio of the number of scheduled departures, without delay or cancellation, to the number of scheduled flights, and the frequency refers to the number of races a company takes on a route over a certain period of time. 
Causes that may adversely affect regularity, and consequently violate the rights of air transport consumers are: weather conditions, technical condition of the appliance, air navigation conditions and the organization of groundhandling services.

Frequency depends on traffic intensity and is determined by economic considerations. On certain short routes, which predominate for passengers traveling on duty, the frequency is also high. On average and long distances, the journey time is longer and the lower the frequency.

Today, air transport is no longer a luxury, but a means of transportation for everyone, as a result of rising living standards, reducing the difference between the cost of an air travel compared to other means of transport. The quality of airline services refers to activities like: check-in, booking of tickets, travel services and comfortable and safe value-added services, such as on-board services, seat comfort and cleanliness, luggage transportation (Perçin, 2018).

There are liner (regular), low-cost or charter airlines. These three types of flights differ mainly in price, destination and schedule.

Air travel is very often used in tourist activity, providing passengers with a high level of comfort, safety and certitude that they can reach their destination in the shortest possible time (Cristea et al., 1980, p 81).

Air travel security is a very important factor in air transport, which is reflected directly in the airline business. Statistics show that the number of people who have lost their lives due to air accidents is much lower compared to other means of transport (http://www.eccromania.ro). The means of air navigation protection are in constant development.

There are five main air operators in Romania that together have more than $75 \%$ of the number of weekly flights. These companies are TAROM, Wizzair, Blue Air, Carpatair and Lufthansa. All these big airlines compete and try to attract as many passengers as possible. Competence makes them better, to offer quality services, and besides, to differentiate themselves with different marketing strategies.

However, air transport service providers sometimes neglect consumers' rights and do not pay much attention to quality and, in particular, material recovery in cases where the moral, sentimental part of the customers is affected. Passengers are better aware of their needs and are more demanding in terms of the quality of the services they have purchased, and if they are not satisfied they are easy to turn to other bidders (Gupta, 2018).

\section{Methodology}

In order to find the satisfaction of air transport customers and the way they perceive their protection activity in this area, the authors conducted a marketing research based on a survey.

The sampling method used was non-aleatory and resulted in a sample of 110 people, structured as can be seen in Table 1.

In order to carry out this research, a questionnaire containing 20 questions, of which 5 are demographic questions, and 15 on the subject opinions and attitudes of the population surveyed on the protection of consumers of air transport services was elaborated. In order to measure respondents' answers to the researched topic, several types of scales were used, 
namely: nominal scale, binary, single-choice nominal scale, multi-choice nominal scale, interval scale, ordinal scale.

He referred to CAWI - Computer Assisted Web Interviewing, a method by which the questionnaire is displayed on a web page, the respondent completing the answers directly in the browser. No additional configurations are required for this method, and no program needs to be installed, with the default browser provided by the operating system. The duration of this study is May 2018 - July 2018. The data collection was carried out on the basis of a questionnaire containing 20 questions.

In terms of gender distribution, $75 \%$ of respondents were females and $25 \%$ male, as can be seen in Figure 1.

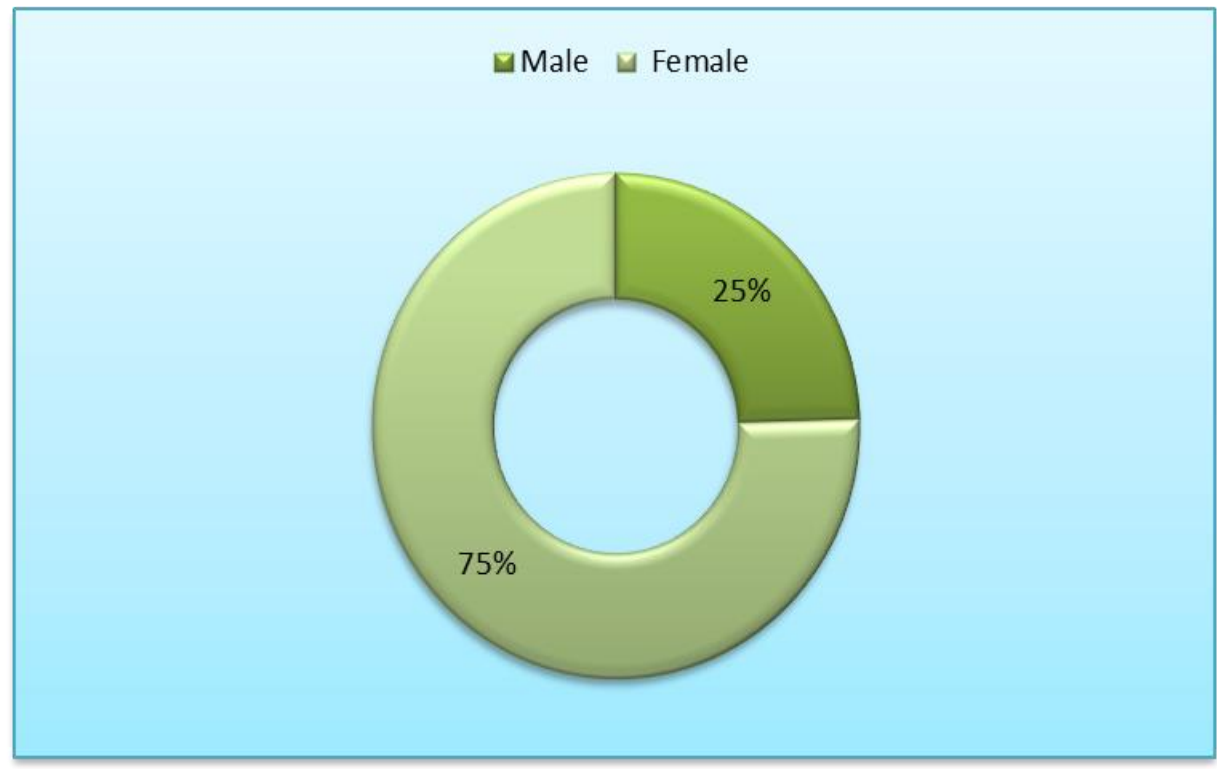

Figure 1. Distribution of people questioned by gender Source: Authors' own research.

The information on age group breakdown of respondents is shown in Table 1.

Table 1. Descriptive information of survey participants

\begin{tabular}{|l|l|l|l|l|}
\hline Age & $\mathbf{1 8 - 3 0}$ years & $\mathbf{3 1 - 4 3}$ years & $\mathbf{4 4 - 5 6}$ years & $\mathbf{5 7 - 6 9}$ years \\
\hline Number & 97 & 5 & 7 & 1 \\
\hline$(\%)$ & 88.18 & 4.55 & 6.36 & 0.91 \\
\hline
\end{tabular}

The objectives of this research are:

- Defining the problems faced by the population surveyed when deciding to benefit from air transport services from accessing the official website to be informed and until they have definitely completed a circle of provision service.

- How well the airlines are prepared from the point of view of protecting consumer rights and meeting all their needs.

- How well respondents know the rights and institutions to which they can appeal when these rights are violated. 


\section{Results and discussions}

The analysis of the respondents' answers showed that all the respondents traveled by plane. Of these, $30.9 \%$ traveled less than once a year, $21.8 \%$ traveled once a year, $20 \%$ traveled twice a year, 20.9\% 3-4 times a year, and 6.4\% more than 4 times a year (Table 2).

Table 2. The frequency with which respondents used air transport services

\begin{tabular}{|l|l|l|l|l|l|}
\hline \multicolumn{2}{|c|}{} & Frequency & Percent & Valid percent & $\begin{array}{l}\text { Cumulative } \\
\text { percent }\end{array}$ \\
\hline \multirow{4}{*}{ Valide } & $\begin{array}{l}\text { Less than once a } \\
\text { year }\end{array}$ & 34 & 30.9 & 30.9 & 30.9 \\
\cline { 2 - 6 } & Once a year & 25 & 21.8 & 21.8 & 52.7 \\
\cline { 2 - 6 } & Twice a year & 21 & 20 & 20 & 72.7 \\
\cline { 2 - 6 } & 3-4 times a year & 23 & 20.9 & 20.9 & 93.6 \\
\cline { 2 - 6 } & Over 4 times a year & 7 & 6.4 & 6.4 & 100.0 \\
\cline { 2 - 6 } & Total & 110 & 100.0 & 100.0 & \\
\hline
\end{tabular}

Source: Authors' own research.

Regarding the choice of the companies they fly, 70\% of the respondents said they had some favorite companies with whom they were traveling, and $30 \%$ said they did not have a preferred travel company (Table 3).

Table 3. The preferred airlines

\begin{tabular}{|l|l|l|l|l|l|}
\hline \multicolumn{2}{|c|}{} & Frequent & Percent & $\begin{array}{l}\text { Valid } \\
\text { Percent }\end{array}$ & $\begin{array}{l}\text { Cumulative } \\
\text { Percent }\end{array}$ \\
\hline \multirow{2}{*}{ Valid } & No & 33 & 30.0 & 30.0 & 30.0 \\
\cline { 2 - 6 } & Yes & 77 & 70.0 & 70.0 & 100.0 \\
\hline
\end{tabular}

Source: Authors' own research.

Of those who responded that they preferred to fly with a particular airline, $12.1 \%$ prefer Tarom, 32.8\% prefer WizzAir, 17.2\% prefer Blue Air, 14.7\% prefer Lufthansa, and 23.2\% prefer other companies. WizzAir, followed by Blue Air, Lufthansa and Tarom, ranked first in the preferences of respondents. A fairly high percentage of people, ie $23.3 \%$ of people, prefer other airlines, among which the most frequent are Turkish Airlines, Ryanair and KLM. Although the Carpatair airline was included as a response, it was not chosen by any respondent (Figure 2). 


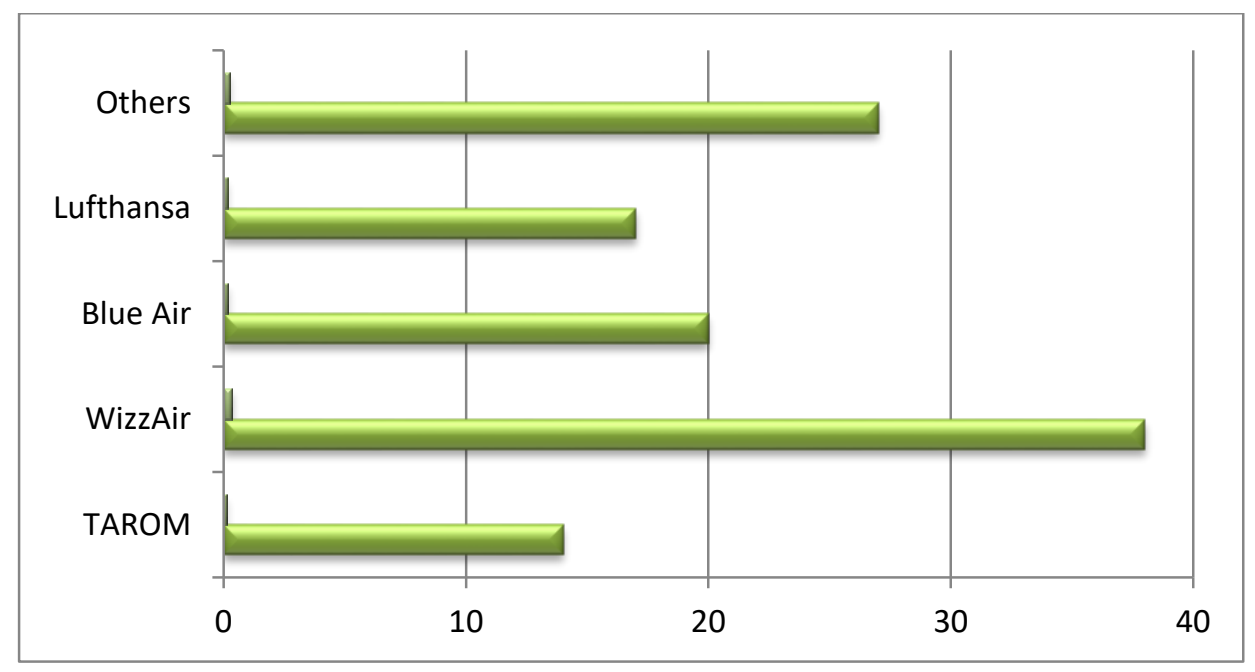

PICBE | 118

Figure 2. The preferred airlines

Source: Authors' own research.

Of the surveyed subjects, the vast majority (91\%) flew by plane because they made holiday trips and only 9\% of respondents said they had business trips (Table 4). As is also emphasized in the literature (Graham et al., 2008; Koo et al., 2017), there is a very close link between tourism and passenger transport. As the air transport market develops, competition between airlines is becoming more and more fierce (Chen et al. 2019).

Table 4. The purpose of trips

\begin{tabular}{|ll|l|l|l|l|}
\hline & Frequency & Percent & $\begin{array}{l}\text { Valid } \\
\text { percent }\end{array}$ & $\begin{array}{l}\text { Cumulative } \\
\text { percent }\end{array}$ \\
\hline \multirow{2}{*}{ Valid } & Business trips & 10 & 10 & 9.09 & 9.09 \\
& Holiday trips & 100 & 90 & 90.91 & 100.0 \\
& Total & 110 & 110.0 & 100.0 & \\
\hline
\end{tabular}

Source: Authors' own research.

The survey focused on passenger satisfaction with the quality of airline services in various aspects, such as the quality-price ratio, the diversity of airline services, airline staff, and unseen situations encountered during the flight.

Researchers generally agree that service quality is an antecedent of customer satisfaction, which in turn leads to customer loyalty (Alegre \& Cladera, 2009; Žabkar et al., 2010; Chen \& Chen, 2010).

Customer satisfaction is defined as a general feeling of pleasure or disappointment that results from comparing the perceived performance of a service or product with pre-service expectations (Oliver, 1980).

Regarding the level of passenger satisfaction (in connection with the diversification of airline services), the vast majority of respondents (56.4\%) said they were satisfied with the collaboration with the chosen company, $22.7 \%$ were very satisfied, $17.3 \%$ said they were 
neither satisfied nor unsatisfied, $2.7 \%$ were unsatisfied and $0.9 \%$ were very unsatisfied (Table 5).

Table 5. The level of satisfaction with the airline

\begin{tabular}{|ll|l|l|l|l|}
\hline & Frequency & Percent & $\begin{array}{l}\text { Valid } \\
\text { percent }\end{array}$ & $\begin{array}{l}\text { Cumulative } \\
\text { percent }\end{array}$ \\
\hline \multirow{6}{*}{ Very satisfied } & 1 & .9 & .9 & 0.9 \\
2,00 & 3 & 2.7 & 2.7 & 3.6 \\
Valid & 3,00 & 19 & 17.3 & 17.3 & 20.9 \\
& 4,00 & 62 & 56.4 & 56.4 & 77.3 \\
& very unsatisfied & 25 & 22.7 & 22.7 & 100.0 \\
Total & 110 & 100.0 & $100 ., 0$ & \\
\hline
\end{tabular}

Source: Authors' own research.

Respondents were asked about the degree of satisfaction with the price-quality ratio of the services offered by the airlines they traveled with. Thus, $40 \%$ of the respondents were satisfied with this ratio, $28.2 \%$ were neither satisfied nor unsatisfied, the same percentage is represented by those very satisfied with the price-quality ratio of these services, $2.7 \%$ were unsatisfied and $0.9 \%$ totally unsatisfied (Table 6).

Table 6. The level of satisfaction with the quality-price ratio

\begin{tabular}{|ll|l|l|l|l|}
\hline & Frequency & Percent & Valid percent & Cumulative percent \\
\hline \multirow{6}{*}{ Very unsatisfied } & 1 & .9 & .9 & .9 \\
& 2,00 & 3 & 2.7 & 2.7 & 3.6 \\
& 3,00 & 31 & 28.2 & 28.2 & 31.8 \\
& 4,00 & 44 & 40.0 & 40.0 & 71.8 \\
& very satisfied & 31 & 28.2 & 28.2 & 100.0 \\
Total & 110 & 100.0 & 100.0 & \\
\hline
\end{tabular}

Source: Authors' own research.

As respect the satisfaction level of those surveyed in relation to airline staff (to which they called), the vast majority of respondents were satisfied with them as follows: $58.2 \%$ of the subjects were satisfied and $25.5 \%$ very satisfied. $12.7 \%$ were either unsatisfied or unsatisfied, and only $3.6 \%$ of the subjects were unsatisfied (Table 7). These percentages indicate that flight crew training programs yield results, and travelers are happy with the attitude and professionalism of their employees. 
Table 7. The level of satisfaction with airline staff

\begin{tabular}{|ll|l|l|l|l|}
\hline & Frequency & Percent & $\begin{array}{l}\text { Valid } \\
\text { percent }\end{array}$ & $\begin{array}{l}\text { Cumulative } \\
\text { percent }\end{array}$ \\
\hline \multirow{6}{*}{ Valid } & very unsatisfied & 0 & 0 & 0 & 0 \\
& $2,00 \quad$ & 4 & 3.6 & 3.6 & 3.6 \\
& 3,00 & 14 & 12.7 & 12.7 & 16.4 \\
& 4,00 & 64 & 58.2 & 58.2 & 74.5 \\
& very satisfied & 28 & 25.5 & 25.5 & 100.0 \\
& Total & 110 & 100.0 & 100.0 & \\
\hline
\end{tabular}

Source: Authors' own research.

A negative aspect that emerged from research is that a large percentage of travelers (39.1\%) encountered unpleasant situations when traveling with airlines (Table 8). These unpleasant situations have prompted them to change their views on the quality of airline services and to reduce their confidence in respecting their rights as consumers of such services.

Table 8. The frequency of unpleasant situations encountered during the flight

\begin{tabular}{|ll|l|l|l|l|}
\hline & & Frequency & Percent & $\begin{array}{l}\text { Valid } \\
\text { percent }\end{array}$ & $\begin{array}{l}\text { Cumulative } \\
\text { percent }\end{array}$ \\
\hline \multirow{3}{*}{ Valid } & no & 67 & 60.9 & 60.9 & 60.9 \\
& yes & 43 & 39.1 & 39.1 & 100.0 \\
& Total & 110 & 100.0 & 100.0 & \\
\hline
\end{tabular}

The most frequent occurrences were the following: flight delay (50\%), postponement of flight (10.3\%), luggage loss (8.6\%), unexpected charge (13.8\%), doubling a place and not receiving it $(6.9 \%)$, other situations $(10.4 \%)$. These issues have been highlighted by other studies showing that passengers are very concerned about reliability issues, including flight schedule and frequency, timing performance and flight safety (Perçin, 2018).

Unfortunately, of those who have experienced unpleasant travel situations, a very small percentage of only $4.3 \%$ turned to the services of consumer protection authorities (Table 9), and they were neither satisfied nor satisfied with the experience which they had with them.

Table 9. The frequency of calling for consumer protection authority

\begin{tabular}{|c|c|c|c|c|c|}
\hline & & Frequency & Percent & Valid percent & Cumulative percent \\
\hline $\begin{array}{l}\text { Valid } \\
\text { Missing } \\
\text { Total }\end{array}$ & $\begin{array}{l}\text { no } \\
\text { yes } \\
\text { Total } \\
99,00\end{array}$ & $\begin{array}{l}41 \\
2 \\
43 \\
67 \\
110\end{array}$ & \begin{tabular}{|l|}
37.3 \\
1.8 \\
39.1 \\
60.9 \\
100.0
\end{tabular} & $\begin{array}{l}95.7 \\
4.3 \\
100.0\end{array}$ & $\begin{array}{l}95.7 \\
100.0\end{array}$ \\
\hline
\end{tabular}

Source: Authors' own research 
The main reasons why most respondents (95.7\%) did not appeal to the services of the National Authority for Consumer Protection were: they did not know the steps to go through (9.8\%), they did not have time (19.6\%), it seemed very complicated (15.7\%), did not significantly disturb the violations of their rights of the airline (47.1\%), other reasons (7.8\%). This situation shows us a phenomenon that unfortunately occurs in other markets: even if consumers are unsatisfied and even if they know their rights have been violated, they do not appeal to the services of the National Consumer Protection Authority and do not react.

The subjects were asked about their level of trust in the work of the Romanian authorities on consumer protection. The answers received showed that $41.8 \%$ of the respondents trust somewhat, 30\% trust much, 9.1\% trust very much, $15.5 \%$ have little confidence and only $3.6 \%$ trust very little in national consumer protection authorities (Table $10)$.

It can be noticed that many of the respondents (39.1\% of them) trust the activity and the possibilities of action of the National Authority for Consumer Protection in the air transport market, which is a positive aspect.

Table 10. The level of consumer confidence in the work of the Romanian authorities on consumer protection

\begin{tabular}{|ll|l|l|l|l|}
\hline & Frequency & Percent & Valid percent & Cumulative percent \\
\hline \multirow{6}{*}{ Valid } & To a very small extent & 4 & 3.6 & 3.6 & 3.6 \\
& 2.00 & 17 & 15.5 & 15.5 & 19.1 \\
& 3.00 & 46 & 41.8 & 41.8 & 60.9 \\
& 4.00 & 33 & 30.0 & 30.0 & 90.9 \\
& To a great extent & 10 & 9.1 & 9.1 & 100.0 \\
& Total & 110 & 100.0 & 100.0 & \\
\hline
\end{tabular}

Source: Authors' own research

In order to know the respondents' opinion about the activity and the possibilities of action of the inspectors of the National Authority for Consumer Protection (NACP), they were asked to express their opinion on the following statement: "The Romanian state can not ensure the protection of consumers because it does not have a great influence on the air transport service providers." $96.4 \%$ of the total population surveyed answered this question. The vast majority (55.7\%) were neither agree nor disagree with the aforementioned statement, which means that the interviewed subjects did not trust the possibilities of NACP inspectors to act on air transport. Of the subjects, $21.7 \%$ agreed and $10.4 \%$ totally agreed with that statement, trusting the work and possibilities of action of NACP inspectors to protect consumers in the air transport market. Only $(8,5 \%)$ were disagreements and $(3,8 \%)$ were totally disagreeing that the Romanian state had no influence on the airlines (Table 10) and even if they had recourse to the services of the National Consumer Protection Authority nothing to be solved. 
Table 10. The opinion on the influence of the Romanian state on airlines

\begin{tabular}{|ll|l|l|l|l|}
\hline & & Frequency & Percent & Valid percent & Cumulative percent \\
\hline \multirow{4}{*}{ total agree } & 11 & 10.0 & 10.4 & 10.4 \\
& agree & 23 & 20.9 & 21.7 & 32.1 \\
Valid aither agree nor & 59 & 53.6 & 55.7 & 87.7 \\
& disagree & & & & 96.2 \\
& disagree & 9 & 8.2 & 8.5 & 100.0 \\
& total disagree & 4 & 3.6 & 3.8 & \\
Missing & Total & 106 & 96.4 & 100.0 & \\
Total & 48.00 & 110 & 3.6 & & \\
\hline
\end{tabular}

Source: Authors' own research

In closing the questionnaire, the subjects were asked how they thought the globalization phenomenon had influenced the protection of airline customers. Most of them $(81.9 \%)$ considered that globalization had a positive influence and led to an increase in the quality of services provided by aviation companies and their increased attention to respecting consumer rights.

\section{Conclusions}

Among the range of tourism transport modes, air transport is possibly the most important and widely used means of travel (Bieger, T., \& Wittmer, A. (2006).

Given the sustained increase in the number of airline passengers (https://ec.europa.eu/eurostat; https://www.iata.org), consumer protection plays a very important role, even though in the market economy producers and service providers tend to meet the needs and wishes of customers for their loyalty.

In the case of air transport services, external factors such as time, political situation of a country, technical problems that companies can not control, but also internal ones, personnel related, lost or damaged baggage have a great influence on quality. For all cases and issues related to this service there are ways to return to a lesser or greater extent the financial, material and moral losses of travelers, only that these companies are not always fulfilling their obligations.

To improve air transport, the efforts of governmental and non-governmental consumer organizations, which have a major role to play in protecting consumer rights, are needed. These authorities need to gain consumer confidence through education and information campaigns by promoting cases where they have managed to support clients whose rights have been violated, by their active involvement in the market economy. In turn, NACP and other institutions and associations in the field need a real feed-back from consumers to plan more effective strategies. Airline companies also need to consider managerial policies such as service efficiency, service diversification, and competence of the flight crew, and tangibles such as on-board services, on-board entertainment and comfort and cleanliness (Perçin, 2018; Chen, 2016).

Tacking into account the number of accidents produced, air transport is considered to be the safest type of transport (https://www.iata.org). 
Passengers' rights in air transport have been improved and increased attention has been paid to the satisfaction of consumers of such services. Consumer protection has positively influenced the quality of air transport services by imposing obligations and providing a very high level of security, which is considered one of the most important aspects in this area. Airline companies in Romania and Europe carry out a permanent assessment of aircraft status (to prevent accidents) and have highly qualified staff (what has been done through employee training).

\section{References}

Alegre, J. \& Cladera, M. (2009). Analysing the effect of satisfaction and previous visits on tourist intentions to return. European Journal of Marketing, 43 (5-6), pp. 670-685

Bieger, T. \& Wittmer, A. (2006). Air transport and tourism- perspectives and challenges for destinations. Journal of Air Transport Management, 12(1), pp.40-46

Bolos, C. \& Leaua, C. (2002). Calitatea - Norme si Legislatie. Editura Universitatii Petru Maior din Targu-Mures, pp. 18

Chen, C.-F. \& Chen, F.-S. (2010). Experience quality, perceived value, satisfaction and behavioral intentions for heritage tourists. Tourism Management, 31 (1), pp. 29-35

Chen, I.S., (2016). A combined MCDM model based on DEMATEL and ANP for the selection of airline service quality improvement criteria: a study based on the Taiwanese airline industry. Journal of Air Transport Management, 57, pp.7-18

Chen, L., Li, Y.Q. \& Liu, C.H. (2019). How airline service quality determines the quantity of repurchase intention - Mediate and moderate effects of brand quality and perceived value. Journal of Air Transport Management, 75, pp. 185-197

Cristea, I., Ionescu, O.C. \& Stanciu, V. (1980). Transportul aerian de pasageri şi de marfă. Editura Tehnică, Bucureşti, p. 81, pp. 125-170

Dudás G., Boros L. \& Vida G. (2017). Comparing the temporal changes of airfares on online travel agency websites and metasearch engines. TOURISM, 65 (2), pp. 187-203

ECC România (2018). Raport anual 2015. Retrieved from http://www.eccromania.ro/media/pdf/Raport_anual_2015.pdf

Eurostat. Air transport of passengers. Retrieved from https://ec.europa.eu/eurostat/tgm/table.do?tab=table\&init=1\&language=en\&pcode $=$ ttr00012\&plugin $=1$

Graham, A., Papatheodorou, A. \& Forsyth, P. (2008). Aviation and Tourism: Implications for Leisure Travel. Ashgate Publishing, Ltd. - nu am pagini

Gupta, H. (2018). Evaluating service quality of airline industry using hybrid best worst method and VIKOR, Journal of Air Transport Management, 68, pp. 35-47

IATA Economics. 2018 in review - air passenger volumes. Retrieved from https://www.iata.org/publications/economics/Reports/pax-monthlyanalysis/passenger_volumes_infog.pdf

IATA Safety. IATA's number \#1 priority. Retrieved from https://www.iata.org/whatwedo/safety/Pages/index.aspx

Koo, T.T.R., Hossein Rashidi, T., Park, J.-W., Wu, C.-L. \& Tseng, W.-C., 2017. The effect of enhanced international air access on the demand for peripheral tourism destinations: evidence from air itinerary choice behaviour of Korean visitors to Australia. Transportation Research Part A: Policy and Practice, 106, pp. 116-129 
Madar, A. (2015). Implementation of total quality management. Case study: British Airways. Bulletin of the Transilvania University of Braşov . Vol. 8 (57), No. 1, pp. 125-132

Neacșu, N. A. (2011). Protecția consumatorului. Editura Universitatii Transilvania din Brasov. Brașov, pp. 27

Neacșu, N. A. (2018). Consumer protection on the banking services market. Bulletin of the Transilvania University of Braşov. Vol. 11 (60), No. 2/2018, pp. 22-28

PICBE | 124

Oliver, R.L., 1980. A cognitive model of the antecedents and consequences of satisfaction decisions. Journal of Marketing Research, 17(4), pp. 460-469

Ordonanţa nr. 21/1992 privind protecţia consumatorilor, 21-02-2018. Retrieved from http://www.anpc.gov.ro/articol/584/legislatie-generala-1

Perçin, S. (2018). Evaluating airline service quality using a combined fuzzy decision-making approach, Journal of Air Transport Management, 68, pp. 48-60

Picu, A.M. \& Capota, V. (2011). Calitatea și protecția consumatorului. Politechnica Press, București, p 34

Raport anual ANPC (2018). Raport anual ANPC 2016, 19-06-2017. Retrieved from http://www.anpc.gov.ro/galerie/file/544/2017/Raport_activitate_ANPC_2016.pdf

Sbora, T., Tănase, Gh. \& Șerban, D. (1979). Economia, organizarea și planificarea transporturilor. Editura Didactică si Pedagogică, București, pp. 20

Strategie protecția consumatorilor (2018). Retrieved from http://www.infocons.ro/ro/pgstrategie-protectia-consumatorilor-MzctMS0yNw.html

Žabkar, V., Brenčič, M.M. \& Dmitrović, T. (2010). Modelling perceived quality, visitor satisfactionand behavioural intentions at the destination level. Tourism Management, 31 (4), pp. 537-546 